\title{
OVERFISHING PADA PERIKANAN PUKAT CINCIN SEMI INDUSTRI DI LAUT JAWA DAN IMPLIKASI PENGELOLAANNYA
}

\author{
Suherman Banon Atmaja1), Bambang Sadhotomo1), dan Duto Nugroho') \\ 1) Peneliti pada Balai Riset Perikanan Laut, Muara Baru-Jakarta \\ 2) Peneliti pada Pusat Penelitian Pengelolaan Perikanan dan Konservasi Sumber Daya Ikan, Ancol-Jakarta \\ Teregistrasi I tanggal: 1 Pebruari 2011; Diterima setelah perbaikan tanggal: 25 Maret 2011; \\ Disetujui terbit tanggal: 6 April 2011
}

\begin{abstract}
ABSTRAK
Krisis perikanan merupakan akibat langsung penangkapan yang berlebihan pada sumber daya perikanan, yang antara lain disebabkan oleh teknologi penangkapan modern. Kini kemungkinan terjadi overfishing karena teknologi telah membuat armada penangkapan lebih mudah menuju ke lokasi gerombolan ikan besar. Overfishing terjadi ketika suatu jenis ikan diambil lebih cepat dibanding dengan pembiakan stok spesies tersebut untuk menghasilkan penggantinya. Pada perikanan pukat cincin semi industri di Laut Jawa, paling sedikitnya telah terjadi economic overfishing, biological overfishing, dan Malthusian overfishing, di mana biaya ekonomi penangkapan yang mahal untuk hasil sedikit, dan nelayan mengorbankan biaya sosial dengan meninggalkan keluarga semakin lama akibat sulit mencari gerombolan ikan.
\end{abstract}

KATA KUNCI: overfishing, pukat cincin, pengelolaan, Laut Jawa

ABSTRACT: Overfishing on purse seine semi industry fisheries in the Java Sea and management implications. By: Suherman Banon Atmaja, Bambang Sadhotomo, and Duto Nugroho

Supposedly fisheries crisis is a direct result of the severe overharvesting of fisheries resources brought about among other by modern fishing technologies. Overfishing is possible today because technology has made it easier to locate large schools of fish and direct fishing fleets to those locations. Overfishing occurs when a species is taken more rapidly than the breeding stock of that species can generate replacements. In the purse seiners semi industry fisheries in the Java Sea, at least there have been economic overfishing, biological overfishing, and Malthusian overfishing, where the economic cost of catching a very high price for a bit, and fishermen have to sacrifice the social cost of leaving the family longer because they are hard to find the fish schooling.

KEYWORDS: $\quad$ overfishing, purse seine, management, Java Sea

\section{PENDAHULUAN}

Dugaan krisis perikanan merupakan akibat langsung dari overharvesting sumber daya perikanan yang parah, yang antara lain disebabkan oleh teknologi penangkapan ikan yang modern. Penggunaan teknologi maju armada penangkapan mengalami perkembangan yang sangat pesat melampaui tingkat hasil tangkapan lestari. Secara umum, ahli perikanan telah mengenali kemerosotan stok sumber daya ikan dunia, kerugian keanekaragaman hayati laut akibat overfishing, polusi, dan tekanan lain seperti perubahan iklim (Mongabay.com., 2006). Pada tahun

Korespondensi penulis: 
terakhir, armada-armada komersial telah berkembang lebih besar, alat tangkap ikan terus meningkat menjadi canggih dan lebih efisien. Sebaliknya sistem pengelolaan perikanan tidak setara dengan perubahan tersebut, sering kali pembiaran penangkapan yang berlebihan dari kemampuan memulihkan dirinya (Fujita, 2008). Perhatian yang terbesar adalah penyusutan populasi ikan yang cepat, sehubungan penangkapan komersial. Pada tahun 2002, 72\% stok ikan laut dunia dipanen lebih cepat daripada tingkat reproduksi. Berdasarkan atas studi empat tahun terkini dari kelompok studi internasional (ahli ilmu lingkungan hidup dan ekonomi) mengatakan bahwa semua makanan laut dari spesies liar kini diproyeksikan ambruk pada tahun 2050, diperkirakan deplesi 90\% (Environment News Service, 2006). Hilborn \& Walters (1992) mengatakan bahwa akar masalah perikanan adalah tidak terkendalinya intervensi manusia dalam mengelola sumber daya perikanan.

Para ahli ekologis mengkhawatirkan usaha terus-menerus untuk mengembangkan perikanan tangkap secara tidak terkontrol dan tidak terkelola secara baik, berdampak pada penurunan kualitas dan kuantitas ekosistem perairan. Sementara tekanan ekologis akibat degradasi habitat, deforesrisasi, konversi lahan pesisir dan penggusuran hutan bakau untuk berbagai kepentingan, pencemaran lainnya dari berbagai kegiatan di hulu, variabilitas lingkungan global dan praktek penangkapan itu sendiri berakibat negatif terhadap kondisi lingkungan kawasan tersebut, dan telah menghancurkan habitat. Pada akhirnya, perubahan ekosistem (ecological collapse) tersebut menyebabkan sulit pemulihan populasi ikan, bahkan populasi ikan akan menuju keseimbangan baru pada tingkat kepadatan yang lebih rendah, juga merugikan ekosistem dengan pemindahan jumlah sebagian besar dari spesies ikan mendorong ke arah perubahan jaringan makanan dari sistem dinamis.

Tulisan ini menggambarkan kondisi perikanan pukat cincin semi industri di Laut Jawa dikaitkan dengan beberapa definisi overfishing.

Bahan tulisan dari berbagai sumber baik yang terkumpul dari studi pustaka maupun dari studi yang pernah dilakukan selama kurun waktu tahun 1992-2008, terutama sumber data berasal dari kapal pukat cincin komersial yang berpangkalan di Pekalongan dan Juwana, yaitu data berupa hasil tangkapan dan upaya penangkapan, serta aktivitas penangkapan berupa jumlah hari laut pada tahun 2009 dan trip/kapal tahun 1995 dan 2010. Sementara parameter model produksi surplus Schaeferyang digunakan dari hasil penelitian Atmaja (2007), yaitu r $=1,385 ; \mathrm{K}=76.000$ ton; $\mathrm{q}=1,05 \times 10^{5}$.

Data dan informasi yang diperoleh disampaikan secara deskriptif dan disajikan dalam tabel-tabel dan gambar.

\section{JENIS OVERFISHING BERDASARKAN ATAS PENDEKATAN YANG BERBEDA}

Overfishing merupakan suatu istilah atau status yang diberikan kepada suatu kawasan perairan yang sumber daya ikannya telah mengalami tangkap lebih. Tangkap lebih yang dimaksud adalah jika laju penangkapan yang dilakukan telah melampaui kemampuan sumber daya ikan tersebut untuk pulih. Konsep tradisional overfishing yang diturunkan dari dinamika populasi dan pendugaan stok spesies tunggal, yaitu growth overfishing, recruitment overfishing, maximum sustainable yield, dan maximum economic yield. Secara implisit, konsep ini termasuk atribut ekosistem seperti asumsi pada pertumbuhan fungsi logistik dalam model 
surplus produksi atau pemasukkan mortalitas alami dalam model dynamic pool (yield per recruit), tetapi nasihat pengelolaan terutama ditujukan untuk spesies tunggal dan kasus perikanan tunggal (Murawski, 2000). Overfishing yang berkaitan dengan dampak sejalan penangkapan (collateral impacts) dikenal dalam tiga bentuk, yaitu bentuk pertama adalah growth overfishing, terjadi ketika ikan ditangkap sebelum sempat tumbuh. Bentuk kedua yang dikenal dengan recruitment overfishing yang menyebabkan pengurangan banyaknya ikan muda yang memasuki daerah penangkapan. Recruitment overfishing dapat dihasilkan oleh 1) penurunan stok induk pemijah, yang menyebabkan jumlah telur yang dihasilkan semakin terbatas dan kemudian peremajaan; dan 2) akibat degradasi habitat yang mempengaruhi kawasan asuhan. Ketiga economic overfishing dan maximum sustainable yield yang diturunkan dari model produksi surplus (Schaeferdan Fox). Economic overfishing terjadi ketika tingkat upaya penangkapan melewati maksimum imbalan ekonomi (maximum economic yield). Pada model surplus produksi tidak membedakan antara growth dan recruitment overfishing tetapi lebih merupakan gabungan kedua proses tersebut ke dalam satu kategori biological overfishing secara umum (Pauly, 1988). Selain ketiga definisi overfishing tersebut, penangkapan sendiri dapat juga merugikan ekosistem dengan pemindahan sejumlah besar dari spesies ikan dan mendorong ke arah perubahan pada dinamika jaringan makanan (food web). Overfishing spesies tertentu tidak hanya merusak populasi ikan itu sendirian, tetapi juga dapat mempunyai pengaruh serius lebih lanjut pada rantai makanan.

Beberapa definsi overfishing dari model surplus produksi diillutrasikan pada Gambar 1 sebagai berikut pemanenan maksimum lestari (maximum sustainable yield) adalah jumlah maksimum teoritis dari ikan bahwa dapat dipindahkan dari suatu populasi tanpa mengangggu kemampuan populasi tersebut untuk memperbaharuinya. Oleh karena itu, Departemen Kelautan dan Perikanan menetapkan sasaran pengelolaan perikanan tangkap Indonesia pada tingkat $80 \%$ dari nilai maximum economic yield atau merupakan tingkat manfaat yang optimal dan berkelanjutan (Undang-Undang Nomor $31 / 2004$ pasal 6 ayat 1) dan secara teoritis keuntungan ekonomi maksimum berada di bawah nilai maximum sustainable yield, setelah $\mathrm{C}_{\mathrm{MEY}}$ merupakan kejadian economic overfishing, sedangkan biological overfishing terjadi setelah maximum sustainable yield tercapai. O'Malley \& Allen (2001) mengatakan bahwa growth overfishing adalah jauh lebih umum dibanding recruitment overfishing, tetapi apabila tidak diberi perhatian menjadi ancaman serius dan akan mengarah pada recruitment overfishing, di mana terjadinya setelah peristiwa keuntungan nol. Penyusutan stok dan ambruk stok disebabkan oleh recruitment overfishing, berarti bahwa populasi induk ikan yang tertangkap sangat bobot, baik jumlah, maupun ukuran populasi induk ikan (biomassa pemijah), sehingga berkurang kapasitas reproduktif untuk pemulihannya. 


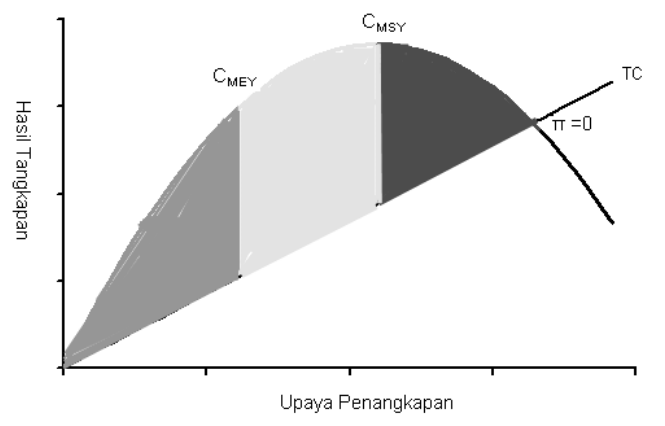

Gambar 1. Illustrasi overfishing dari kurva hasil tangkapan lestari.

Figure 1. Illustration of overfishing from sustainable yield curve.

Sumber/Sources: Pauly (1988); O’Malley \& Allen (2001)

Uraian lebih rinci tentang beberapa overfishing dari sejumlah perspektif berbeda sebagai berikut:

1. Economic overfishing, yaitu penangkapan saat tingkat upaya penangkapan lebih besar daripada imbalan ekonomi (economic rent) sumber daya ikan atau prinsip maksimisasi profit atau keuntungan. Tingkat optimum upaya penangkapan yang menghasilkan hasil tangkap maksimum secara ekonomi (maximum economic yield) adalah lebih rendah daripada upaya penangkapan pada saat maximum sustainable yield. Dengan demikian, keuntungan optimal terjadi pada saat maximum economic yield, di mana marginal revenue adalah sama dengan marginal cost.

2. Biological overfishing yaitu gabungan growth overfishing dan recruitment overfishing, yang terjadi ketika tingkat pemanfaatan yang telah ditetapkan mengakibatkan penurunan hasil tangkapan secara keseluruhan, atau upaya penangkapan telah melampaui upaya penangkapan optimum pada tingkat maximum sustainable yield atau terjadi ketika mortalitas penangkapan telah mencapai tingkat di mana biomassa stok telah mengalami pertumbuhan marginal negatif (slowing down biomass growth).

3. Growth overfishing, terjadi ketika ikan dipanen pada rata-rata ukuran yang lebih kecil dibanding ukuran yang akan menghasilkan maximum yield per recruit atau banyaknya ikan muda yang memasuki perikanan tertangkap oleh perikanan utama sebelum tumbuh menjadi ukuran optimum pasar. Proses menangkap ikan tersebut mengakibatkan penurunan rata-rata ukuran dari populasi ikan. Situasi ini pada spesies berumur panjang akan mempengaruhi matang seksual terlambat. Bentuk overfishing ini disebabkan penggunaan jaring dengan ukuran mata jaring kecil. Pencegahan growth overfishing dapat dilakukan dengan beberapa cara, misalnya pembatasan upaya penangkapan, pengaturan ukuran mata jaring, dan penutupan musim atau daerah penangkapan.

4. Recruitment overfishing, awal penggunaan istilah recruitment overfishing menggambarkan kemunduran yang tajam dalam recruitment terjadi ketika stok induk ikan (spawning stock) berkurang (Cushing, 1976 dalam Sainsbury \& Polacheck, 1994). Definisi recruitment overfishing adalah pada hakekatnya penurunan recruitment yang tajam akibat suatu kombinasi rendahnya biomassa induk ikan (spawning biomass), mortalitas penangkapan yang tinggi. Definisi yang berbeda adalah pengurangan stok induk ikan dan pengurangan potensi habitat pemijahan dan kawasan asuhan (Sainsbury \& Polacheck, 1994). Dengan demikian recruitment overfishing kebalikan dari kasus growth overfishing, 
di mana kegiatan penangkapan telah menyebabkan berkurang stok induk ikan dan degradasi lingkungan pesisir akibat pengambilan ikan-ikan juvenil di perairan pesisir, akhirnya berkurangnya jumlah ikan muda atau yang masuk ke daerah penangkapan. Pada perikanan pelagis kecil, situasi ini berbahaya dan dapat menyebabkan ambruk perikanan, seperti pada spesies sardenella atau sejenis ikan hering. Oleh karena itu, perlu proteksi terhadap gerombolan induk ikan (spawning agregation) di kawasan daerah pemijahan.

5. Ecosystem overfishing, suatu karakteristik dari overfished ecosystems adalah deplesi urutan stok ekonomis. Peralihan antara spesies sasaran terjadi ketika sumber daya ekomomis penting jelas berkurang kelimpahannya, sebaliknya kelimpahan stok lain berlebihan (Murawski, 2000). Beberapa overfishing ini memandu spesies terhadap pemunahan ekologis karena populasi-populasi ikan yang lebih tangkap tidak lagi berinteraksi dengan mantap dengan spesies lain dalam komunitas. Overfishing dan pemunahan ekologis mendahului prasyarat penyelidikan ekologis modern dan ambruk dari ekosistem-ekosistem laut akhir-akhir ini, dan kemungkinan banyak ekosistem laut lain berbahaya terhadap ambruk perikanan di masa mendatang (Jackson et al., 2001). Dengan demikian ecosystem overfishing, berdasarkan atas pertimbangan ilmiah kini diarahkan terhadap evaluasi ekosistem mengenai faktor penentu dari produksi ikan (seperti produksi primer, efisiensi trofik, dan keanekaragaman spesies) dan pengaruh faktor-faktor penting proses dalam ekosistem, serta hubungan timbal balik (Pauly \& Christensen, 1995). Struktural utama dan perubahan fungsi ekosistem dampak sejalan penangkapan, yaitu perubahan struktur trophic dari ekosistem-ekosistem laut, seperti hasil sampingan (bycatch, pembunuhan spesies non target) dan kerusakkan habitat (gangguan secara fisik yang membunuh kehidupan dasar perairan). Suatu strategi penangkapan ikan yang disertai deplesi urutan stok highertrophic-level adalah beresiko (Christensen, 1996). Bukti dari catatan retrospektif mengatakan bahwa struktural utama dan perubahan fungsi sehubungan overfishing terjadi di ekosistem-ekosistem pantai seluruh dunia. Perubahan iklim memperburuk situasi perikanan dengan meningkatkan kadar keasaman laut dan pemutihan terumbu karang, mengancam habitat ikan bertelur dan daerah asuhan (nursery), pergeseran arus-arus lautan dan planktonnya, serta ikan kecil dalam rantai makanan lautan (Jackson et al., 2001). Dengan demikian, konsep bentuk overfishing ini diperkenalkan untuk menjelaskan karakteristik proses dampak sejalan penangkapan yang sangat intensif sampai meubah keseimbangan spesies yang ada di daerah penangkapan, meskipun beberapa spesies (non target spesies) meningkat jumlahnya tetapi gagal menggantikan spesies lain yang berkurang atau suatu pemindahan organisme mendorong ke arah dampak merugikan seluruh sistem.

6. Malthusian overfishing, konsep Malthusian overfishing diperkenalkan oleh Pauly et al. (1989) untuk menggambarkan situasi eksploitasi yang berlebihan pada perikanan skala kecil di pantai tropis negara-negara berkembang, terutama di Asia Tenggara. Dalam memenuhi kebutuhan dasar hidupnya dan sumber protein hewani cenderung merusak sumber daya dengan praktek penangkapan yang merusak habitat dan ekosistem. Situasi ini terutama disebabkan oleh kelebihan 
populasi nelayan atas sumber daya yang tersedia, dan ketidakmampuan dari nelayan untuk pindah ke bentuk pekerjaan lain atau tidak memiliki alternatif mata pencaharian. Sunderlin (1994) mengatakan bahwa Malthusian overfishing menunjukkan kondisi lingkungan sosial, ekonomi perikanan tangkap, kemiskinan, pertumbuhan populasi, dan ketiadaan alternatif mata pencarian. Secara umum, overfishing Malthusian adalah suatu ungkapan untuk menggambarkan suatu situasi yang terjadi ketika penangkapan terlalu intensif dengan menggunakan alat tangkap yang tidak selektif dan praktek penangkapan yang merusak habitat mengakibatkan merugikan ekosistem, pada akhirnya terjadi penurunan hasil tangkapan. Pauly (1993) mengatakan karakteristik yang menunjukkan adanya jenis overfishing ini di suatu perikanan, adalah termasuk suatu peningkatan jumlah nelayan; penurunan tangkapan dan pendapatan per nelayan; bukti biological dan ecological overfishing; economic overfishing; uraian strategi pengelolaan menurut tradisional; tidak adanya atau tidak efektifnya regulasi pengelolaan; masuknya nelayan baru dengan tidak adanya tradisi penangkapan; dan peningkatan penggunaan alat tangkap yang tidak ramah lingkungan; Boedhihartono \& Kasri (2000) menyimpulkan bahwa yang hidup dalam kemiskinan cenderung untuk merambah dan merusak lingkungan sekedar untuk hidup, mengabaikan dan melalaikan semua kemungkinan yang berakibat merugikan. Neo Malthusians (pemikiran ecocentric) kelompok ini melihat kelebihan penduduk sebagai kunci permasalahan zona pantai. Cara yang paling mudah untuk memecahkan permasalahan zona ekologi pantai melalui kendali pertumbuhan populasi.

\section{OVERFISHING PADA PERIKANAN PELAGIS KECIL DI LAUT JAWA}

Dari kondisi perikanan pukat cincin semi industri (Gambar 2) dapat disimpulkan dari patokan (criteria) overfishing paling sedikitnya telah mengalami economic overfishing, biological overfishing, dan Malthusian overfishing. Economic overfishing ditunjukkan dengan biaya ekonomi (economic cost) penangkapan yang mahal untuk hasil lebih sedikit, dan biaya sosial (social cost) meninggalkan keluarga semakin lama akibat sulit mencari gerombolan ikan. Kini rata-rata jumlah hari operasi kapal pukat cincin berkisar 53-84 hari (Gambar 3 dan Tabel 1), sedangkan selama 15 tahun aktivitas penangkapan menurun tajam dari rata-rata trip/kapal sekitar 7,8 trip/kapal (simpangan baku = 2,5) pada tahun 1995 menjadi sekitar 2,3 trip/kapal (simpangan baku $=0,84$ ) pada tahun 2010.

Malthusian overfishing pada perikanan pukat cincin semi industri, nelayan yang memasuki perikanan tangkap akan berhadapan dengan hasil tangkapan yang cenderung menurun. Untuk memperoleh hasil tangkapan yang memadai berkorban tinggal di laut yang lama. Apabila sekiranya ada alternatif lapangan pekerjaan yang lebih baik, tentu tidak memilih menjadi anak buah kapal pukat cincin semi industri dengan hasil yang tidak menentu.

Sementara biological overfishing, terutama recruitment overfishing dapat diperdebatan lebih lanjut. Recruitment overfishing akibat sebagian besar ikan yang tertangkap belum matang seksual yang terjadi bertahun-tahun dan rantaian progresif lemahnya pengelolaan, yang telah mengurangi stok induk ikan (spawning stock). Widodo (1989) menyimpulkan berdasarkan atas hasil simulasi pengaruh ukuran mata jaring 10,15, dan $20 \mathrm{~mm}$ dari 
aplikasi model Beverton dan Holt, peningkatan ukuran mata jaring dari $15 \mathrm{~mm}$ menjadi $20 \mathrm{~mm}$ akan menurunkan hasil tangkapan, penurunan ukuran mata jaring dari $15 \mathrm{~mm}$ menjadi $10 \mathrm{~mm}$ selain akan meningkatan hasil tangkapan, juga akan menyebabkan terjadinya growth overfishing di mana banyak ikan-ikan berukuran kecil dan ikan-ikan muda tertangkap. Berdasarkan atas hasil penelitian aspek reproduksi tertangkapnya induk ikan matang gonad tidak dalam bentuk gerombolan (Atmaja, 2008). Dengan demikian, pendekatan memelihara stok induk ikan (spawning stock) melalui larangan penangkapan atau perlindungan ikan yang akan bertelur, melalui penutupan daerah dan musim penangkapan belum mempunyai alasan kuat.

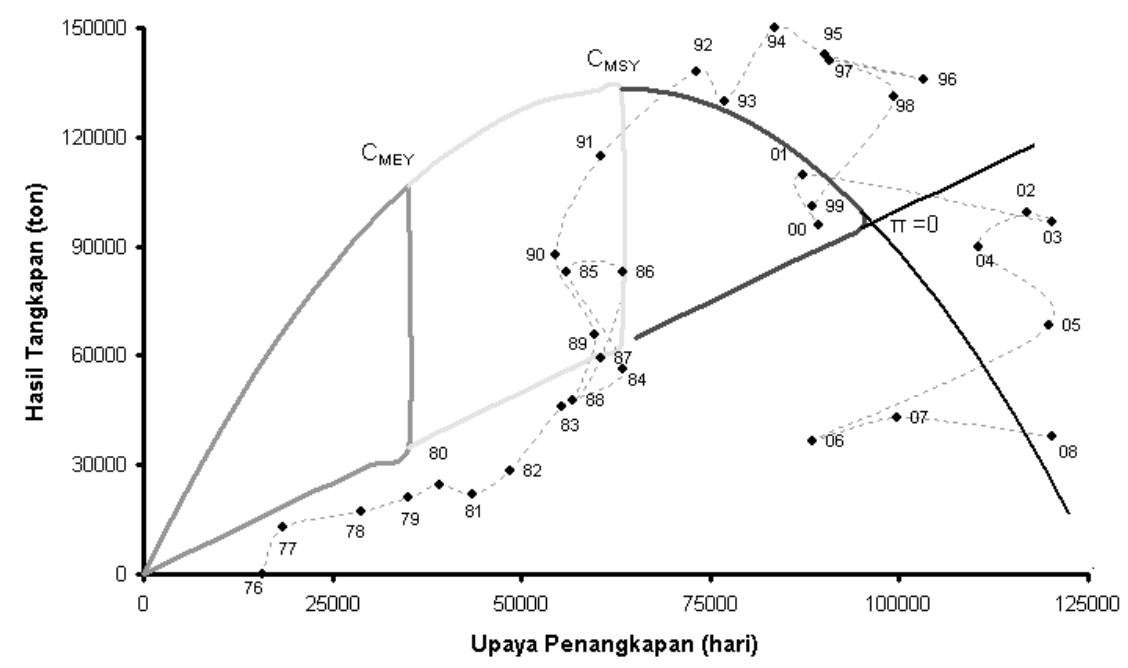

Gambar 2. Situasi perikanan pukat cincin semi industri.

Figure 2. Situation the purse seiners semi industry fisheries. 
Tabel. 1 Rata-rata jumlah hari operasi kapal pukat cincin GT $>30$ ton

Table 1. Average day at sea of purse seiners $G T>30$

\begin{tabular}{|c|c|c|c|c|}
\hline & \multicolumn{3}{|c|}{ Pekalongan } & \multirow{2}{*}{$\begin{array}{c}\text { Juwana } \\
\text { Junlah hari laut }{ }^{\star} / \\
\text { The number of sea days }{ }^{\star}\end{array}$} \\
\hline & $\begin{array}{c}\text { Jumlah hari laut }{ }^{\star} / \\
\text { The number of sea days }\end{array}$ & $\begin{array}{l}\text { Trip/kapal } \\
1995\end{array}$ & $\begin{array}{c}\text { Trip/kapal } \\
2010\end{array}$ & \\
\hline Rata-rata & 83,6 & 7,8 & 2,3 & 52,7 \\
\hline SD & 21,8 & 2,5 & 0,84 & 21,5 \\
\hline $\mathrm{N}$ & 498 & 358 & 150 & 150 \\
\hline
\end{tabular}

\section{IMPLIKASI PENGELOLAAN PERIKANAN PELAGIS KECIL DI LAUT JAWA}

Kondisi perikanan Indonesia tidak jauh berbeda dengan kondisi perikanan dunia pada umumnya. Secara alami, nelayan mempunyai pengalaman historis yang fleksibel dan adaptif dalam usaha perikanan, sebagaimana terus-menerus dihadapkan pada suatu situasi perubahan lingkungan eksternalnya. Pada situasi penyusutan stok ikan, sebagian kapal pukat cincin telah melakukan diversifikasi usaha dengan mengganti perangkat penangkapannya, dengan mengalihkan sebagian kapal menjadi alat tangkap cumi-cumi dan cantrang. Sejak tahun 2009 telah berkembang pukat cincin mini khusus untuk menangkap ikan tongkol (Euthynnus affinis) di Laut Jawa. Hal ini dapat dimasukkan dalam strategi rotasi eksploitasi. Kompleksitas pengelolaan perikanan ini akan menimbulkan banyak kesulitan bagi manajer perikanan, karena adanya kesenjangan antara pengalaman nelayan dengan regulator dan penelitian, seperti pemahaman yang kurang tentang bagaimana ekosistem perikanan bekerja dan bagaimana spesies yang berbeda berinteraksi atau dipengaruhi oleh gangguan lain atau kegiatan ekonomi. Oleh karena itu, seluruh ekosistem dan pengelolaan multi species tidak mudah diterjemahkan ke dalam strategi pengelolaan perikanan. Dengan demikian pendekatan kehati-hatian dan konservatif (precautionary dan conservative approach) mendukung perencanaan pengelolaan perikanan dan proses pengambilan keputusan.

Upaya pemulihan populasi ikan telah menjadi program penting dalam negosiasi nasional dan komitmen tentang keberlanjutan. Pengembangan rencana pemulihan stok ikan pelagis kecil di Laut Jawa melalui perubahan paradigma open access ke quasi open access sampai ke limited access. Penghentian izin baru kapal pukat cincin berlaku mulai tanggal 15 Maret 2010 (Keputusan Direktur Jenderal Perikanan Tangkap Nomor 08/09-PT/2010), dan salah satu hasil rumusan rekomendasi rencana pengelolaan perikanan adalah menutup secara bertahap penambahan kapal penangkapan baru khususnya untuk kapal-kapal di atas $30 \mathrm{GT}$, dan merelokasi kapal penangkapan ke wilayah pengelolaan perikanan yang dalam kondisi under exploited. Kini sebagian besar kapal pukat cincin semi industri telah merelokasi daerah penangkapan ke perairan Laut Maluku dan Samudera Hindia untuk menangkap ikan pelagis besar. Pembentukan sistem pemantauan kapal perikanan (vessel monitoring system) untuk melaksanakan pengawasan di bidang penangkapan dan/ atau pengangkutan ikan, sebagaimana diamanatkan dalam Undang-Undang Nomor 31 tahun 2004 tentang perikanan. 
Namun demikian, perubahan dan pergeseran perilaku pengusaha atau nelayan kurang menjadi perhatian. Selama dua dekade terakhir telah menjadi perhatian terutama terhadap alokasi spasial dari upaya penangkapan. Bagaimana pun pengetahuan tentang perilaku nelayan sangat penting untuk pengelolaan perikanan yang efektif. Kurangnya pengetahuan di bidang ini diperkirakan menjadi penyebab utama runtuhnya beberapa perikanan (Hilborn, 1985). Kumpulan perilaku tentang armada penangkapan dapat diramalkan dan dikelola dengan insentif yang sesuai, dan pengembangan upaya penangkapan perlu dikendalikan (Hilborn, 2007). Pada akhirnya, pengelolaan perikanan komersial jelas memerlukan pemahaman ilmiah yang baik perilaku stok yang dieksploitasi. Pendekatan pengelolaan yang berhasil cenderung untuk menggabungkan sistem berbasis hak (rights based systems), memberi insentif bagi nelayan yang beroperasi secara efisien dan berpikir keberlanjutan jangka panjang, struktur hukum yang kuat dengan pengembangan strategi pra panen disepakati (pre agreed harvest strategies) dan aturan-aturan keputusan dipatuhi sebagai titik acuan, serta suatu pengendalian yang memadai terhadap kegiatan perikanan juga diperlukan (Beddington et al., 2007.)

\section{KESIMPULAN}

1. Economic overfishing, biological overfishing, dan Malthusian overfishing. Suatu bejana sehubungan mismanagement adalah kerugian sosial dan ekonomi.

2. Pertimbangan dellima sosial maka strategi rotasi eksploitasi dapat menjadi pilihan regulasi perikanan tangkap, dengan suatu pengendalian yang memadai terhadap kegiatan perikanan.
3. Walaupun, di Indonesia telah memiliki peraturan penangkapan ikan yang dikeluarkan oleh pemerintah (Departemen Perikanan dan Kelautan), seperti peraturan tentang ukuran mata jaring, pengaturan daerah penangkapan, dan pengaturan alat tangkap, namun pada kenyataannya peraturan-peraturan ini sulit dilaksanakan, sebagai contoh perubahan pukat cincin menjadi cantrang lebih berdasarkan atas pertimbangan aspek sosial dan ekonomi. Suatu hal yang tidak mengherankan, karena bagaimanapun pemerintah daerah akan memaksimum tenaga kerja bagi penduduknya.

\section{DAFTAR PUSTAKA}

Atmaja, S. B. 2007. Ketidakpastian besaran stok ikan dari model produksi surplus. Jurnal Penelitian Perikanan Indonesia. 13 (1): $1-9$.

. 2008. Sumber Daya Ikan Pelagis Kecil dan Dinamika Perikanan Pukat Cincin di Laut Jawa dan Sekitarnya. Balai Riset Perikanan Laut. Pusat Riset Perikanan Tangkap. Badan Riset Kelautan dan Perikanan. 100 pp.

Boedhihartono \& N. Kasri. 2000. How Societal Thinking Shapes Attitudes to Resource Exploitation/Indonesia. Department of Anthropology. University of Indonesia. Wise Coastal Practices for Sustainable Human Development Forum. http:// www.csiwisepractices.org/

Beddington, J. R., D. J. Agnew, \& C. W. Clark. 2007. Current problems in the management of marine fisheries. Science. $316(5,832):$ 1,713-1,716.

Christensen, V. 1996. Managing fisheries involving top predator and prey species components. Reviews in Fish Biology and Fisheries. 6: 417-442. 
Environment News Service. 2006. Collapse of All Wild Fisheries Predicted in 45 Years November 6, 2006. www.ensnewswire.com/ens/nov2006/2006-11-0602.asp-41k.

Fujita, R. 2008. Individual Fishing Quotas: $A$ Win-Win Tool for Fisheries and Fishermen. An interview with our Expert Rod Fujita. www.edf.org/article.cfm

Hilborn, R. 1985. Fleet dynamics and individual variation: Why some people catch more fish than others. Can. J. Fish. Aquat. Sci. 42: 2-13.

Hilborn, R. \& C. J. Walters. 1992. Quantitative Fisheries Stock Assessment: Choice, Dynamics, and Uncertainty. Chapman and Hall. New York. London. 570 pp.

Hilborn, R. 2007. Managing fisheries is managing people: What has been learned? Fish and Fisheries. 8 (4): 285-296.

Jackson, J. B. C., M. X. Kirby, W. H. Berger, K. A. Bjorndal, L. W. Botsford, B. J. Bourque, R. H. Bradbury, R. Cooke, J. Erlandson, J. A. Estes, T. P. Hughes, S. Kidwell, C. B. Lange, H. S. Lenihan, J. M. Pandolfi, C. H. Peterson, R. S. Steneck, M. J. Tegner, \& R. R. Warner. 2001. Historical overfishing and the recent collapse of coastal ecosystems. Science. 293: 629-638.

Murawski, S. A. 2000. Definitions of overfishing from an ecosystem perspective. ICES Journal of Marine Science. 57: 649-658.

Mongabay.com. 2006. All Stocks of Wild Seafood Species to Collapse by 2048 Says New Study. November 2, 2006. www.mongabay.com/news-index / fishing2.html-25k.
O’Malley, J. M. \& D. Allen. 2001. Growth Overfishing. http:// www.lobsterconservation.com/ growthoverfishing

Pauly, D. 1988. Some definitions of overfishing relevant to coastal zone management in Southeast Asia. Tropical Coastal Area Management. 3 (1): 14-15.

Pauly, D., G. Silvestre, \& I. R. Smith. 1989. On development, fisheries, and dynamite: A brief review of tropical fisheries management. Natural Resource Modeling. 3 (3): 307-29.

Pauly, D. 1993. From growth to Malthusian overfishing: stages of fisheries resources misuse. South Pacific Commission. Traditional Marine Resource Management and Knowledge Information Bulletin. 3: 714.

Pauly, D. \& V. Christensen. 1995. Primary production required to sustain global fisheries. Nature. 374: 255-257.

Sunderlin, W. D. 1994. Beyond Malthusian overfishing: The importance of structural and non demographic factors. Traditional Marine Resource Management and Knowledge Information Bulletin. 4:2-6.

Sainsbury, K. \& T. Polacheck. 1994. The use of biological reference points for defining recruitment overfishing with an application to Southern Bluefin Tuna. Population Dynamics for Fisheries Management. Australian Society for Fish Biology Proceedings. 265-274.

Widodo. J. 1989. Pendugaan pra linier pengaruh berbagai perubahan atas bawah ukuran ikan dan intensitas penangkapan terhadap perikanan pelagis kecil di Laut Jawa. Jurnal Penelitian Perikanan Laut. 51:67-78. 